\title{
PERKEMBANGAN TATA URUTAN PERATURAN PERUNDANG- UNDANGAN YANG PERNAH ADA DI INDONESIA
}

\author{
ADINDA FEBRIAN GUMANTI \\ Email:adindafebriangumanti17@gmail.com \\ No BP:1910003600029 \\ Univertas Ekasakti-AAI Padang \\ Fakultas Hukum
}

\section{A.PENDAHULUAN}

Hukum adalah suatu sistem yang di dalamnya terdapat norma-norma dan aturan-aturan yang mengatur tingkah laku manusia.Ada pula yang menyebutkan hukum merupakan aturan yang tertulis maupun tidak tertulis yang dapat mengatur masyarakat dan dikenai sanksi jika melanggarnya.

Dengan adanya hukum,tingkat kejahatan akan berkurang.Pemegang kekuasaan tidak dapat berlaku sewenang-wenang karena telah dibatasi oleh hukum.Selain itu hukum membantu untuk melindungi hak dan kewajiban setiap warga negara.Maka dari itu negara harus memiliki sistem hukum yang tepat.

Ketika hukum ditegakkan, maka perkara akan diselesaikan. Dalam penyelesaiannya perlu melalui proses pengadilan yang sesuai dengan aturan yang berlaku. Hakikatnya, tujuan hukum yaitu universal dengan terwujudnya ketentraman, ketertiban dan kesejahteraan masyarakat.

Hukum juga memiliki beberapa tujuan. Dengan adanya hukum, kemakmuran masyarakat akan terjamin. Pergaulan masyarakat akan lebih tertata dan menjadi petunjuk atau pedoman dalam menghadapi keputusan negara. Hukum juga digunakan sebagai sarana mewujudkan keadilan sosial dan sebagai penegak pembangunan.Semua hukum yang berlaku di negara manapun pasti memiliki unsur tersendiri.Dengan begitu,hukum yang berlaku dapat diakui oleh warga negara tersebut. 
Hukum memiliki banyak cabang antara lain hukum administrasi negara,hukum internasional dan hukum tata negara,hukum tata negara juga merupakan sebuah hukum yang wajib kita ketahui tentang apa-apa saja yang harus dibahas dalam hukum tata negara ini,oleh karena itu tujuan saya membuat atau mengangkat hokum tata negara sebagai tema makalah saya adalah untuk bisa menambah wawasan kita tentang apa itu hukum tata negara tersebut.

Rumusan masalah :

1.Apa itu hukum tata negara?

2.Pengertian hukum tata negara menurut para ahli?

3.Hukum tata negara mempelajari tentang apa?

4.Perkembangan tata urutan peraturan perundang-undangan yang pernah ada di Indonesia?

5.Tujuan hukum tata negara?

6.Fungsi hukum tata negara?

7.Asas-asas hukum tata negara? 


\section{B.PEMBAHASAN}

\section{Apa Itu Hukum Tata Negara?}

Hukum tata negara adalah bentuk hukum yang mendefinisikan hubungan antara berbagai lembaga di dalam suatu negara, yaitu eksekutif,$\underline{\text { legislatif, dan yudikatif. }}$

Tidak semua negara bangsa memiliki konstitusi, walaupun semua negara semacam itu memiliki jus commune, atau hukum tanah air yang berisi sejumlah peraturan imperatif dan konsensus. Peraturan tersebut meliputi hukum adat, konvensi, hukum statuta, hukum hakim, atau peraturan dan norma internasional.

Hukum tata negara juga merupakan cabang hukum yang mengatur tentang norma dan prinsip hukum yang tertulis dalam praktek kenegaraan. Hukum tata negara mengatur hal-hal berhubungan kenegaraan seperti bentuk-bentuk dan susunan negara, tugas-tugas negara, perlengkapan negara, serta hubungan alat perlengkapan negara tersebut.

Selain pengertian secara umum, ada pula pengertian menurut para ahli.Salah satu ahli yang mengemukakan pendapatnya mengenai pengertian hukum tata negara adalah Van der Pot, dimana ia mengatakan bahwa hukum tata negara adalah peraturan-peraturan yang menentukan badan-badan yang diperlukan serta wewenang masing-masing, hubungannya satu dengan yang lain dan hubungan dengan individu yang lain.

Selain Van der Pot ahli lain yang mengemukakan pendapatnya adalah Scholten.Hampir mirip dengan Van der Pot, ia mengatakan bahwa hukum tata negara adalah hukum yang mengatur organisasi dari pada Negara.Kesimpulannya, menurut Scholten bahwa dalam organisasi negara itu telah dicakup bagaimana kedudukan organ-organ dalam negara itu, hubungan, hak dan 
kewajiban, serta tugasnya masing-masing.pendapat dari ahli yang terakhir sebelum kita sampai pada contoh hukum tata negara adalah pendapat menurut Apeldoorn.Menurutnya Hukum tata negara dalam arti sempit yang sama artinya dengan istilah hukum tata negara dalam arti sempit,adalah untuk membedakannya dengan hukum negara dalam arti luas, yang meliputi hukum tata negara dan hukum administrasi negara itu sendiri.

Dengan adanya pengetian bahwa hukum tata negara mengatur tentang bentuk-bentuk dan susunan negara, dan sebagainya.Maka jika kita melihat di Indonesia ada banyak lembaga-lembaga seperti Presiden, DPR, DPD, dan sebagainya maka itulah salah satu contoh dari hal yang diatur dalam hukum tata negara.Selain itu dalam hukum tata negara juga diatur hubungan pemerintah pusat dan daerah.Kurang lebih seperti itulah gambaran contoh hal yang diatur dalam hukum tata negara.

\section{Pengertian Hukum Tata Negara Menurut Para Ahli}

1. Van der Pot,Hukum tata negara merupakan serangkaian peraturan yang digunakan untuk menentukan badan mana saja yang digunakan dan diperlukan, kewenangan masing-masing badan,hubungan anatara badan satu dengan badan yang lain, serta hubungan dengan individuindividu didalam suatu negara.

2. Van Vollen Hoven,Hukum tata negara merupakan hukum yang mengatur individundividu yang terikat dengan hukum, serta hukum yang menentukan sistematika penyusuanan wewenang suatu badan-badan tersebut

3. Logemann,Hukum Tata Negara adalah hukum yang mengatur organisasi Negara.menurut 
4. Mac Iver,Negara merupakan Organisasi politik yang ada di dalam masyarakat, tetapi negara itu bukan bentuk dari masyarakat. Negara merupakan organisasi dalam masyarakat, yaitu organisatie-kapstok.

5. Prof. Kusumadi Pudjosewojo, S.H.,Dalam bukunya Pedoman Pelajaran Tata Hukum Indonesia menyebutkan bahwa:"Hukum Tata Negara ialah hukum yang mengatur tata negara (kesatuan atau federal),dan bentuk pemerintahan (kerajaan atau revublik), yang menunjukan masyarakat-masyarakat hukum yang atasan maupun yang bawahan, beserta tingkatantingkatan (hierarchie), yang selanjutnya menegaskan wilayah dan lingkungan rakyat dari masyarakat hukumitu dan akhirnya akhirnya menunjukan paerlenglkapan dari masyarakat hukum itu sendiri.

6. Vollenhoven,Hukum tata negara membahas masyarakat hukum atasan dan masyarakat Hukum bawahan serta hubungannya menurut hierarkhi serta hak dan kewajiban masing-masing, dan dari masing-masing itu menentukan wilayah lingkungan masyarakatnya ,semua itu menunjukkan negara dalam keadaan statis.

Ruang lingkup pengaturan hukum tata negara antara lain meliputi, bentuk negara, bentuk pemerintahan, sistem pemerintahan, corak pemerintahan, sistem pendelegasian kekuasaan negara, garis-garis besar tentang organisasi pelaksana, wilayah negara, hubungan antara rakyat dengan negara, cara-cara rakyat menjalankan hak-hak ketatanegaraan, dasar negara dan ciri-ciri lahir kepribadian negara termasuk lagu kebangsaan, bahasa nasional, lambang bendera dan lain sebagainya. 


\section{Yang Dipelajari dalam Hukum Tata Negara}

Hukum Tata Negara mempelajari berbagai teori dan praktik dalam penyelenggaraan yang dikenal di berbagai negara.Hukum Tata Negara mencakup berbagai isu mengenai relasi antarlembaga negara dan antara negara dan warganya:bagaimana negara ditata, diorganisasikan,untuk dikelola dalam mencapai tujuan negara.Meskipun tidak semua negara memiliki satu konstitusi tertulis, organisasi negara pada umumnya didokumentasikan dalam sebuah undang-undang dasar yang berlaku sebagai hukum yang mendasari negara itu, to constitute the country.Karena itu, hukum tata negara dikenal juga sebagai "constitutional law,"yaitu bagaimana dasar-dasar pengaturan mengenai negara disusun, dipraktikkan, dan berkembang.

\section{Perkembangan Tata Peraturan Perundang-undangan yang Pernah ada di Indonesia}

Tap MPRS NO. XX/MPRS/1996 tentang Memorandum DPR-GR mengenai sumber tertib hukum Republik Indonesia dan tata urutan perundang-undangan Republik Indonesia.

Urutannya yaitu :

1.UUD 1945;

2.Ketetapan MPR;

3.UU;

4.Peraturan Pemerintah;

5.Keputusan Presiden;

6.Peraturan Pelaksana yang terdiri dari : Peraturan Menteri dan Instruksi Menteri.Ketentuan dalam Tap MPR ini sudah tidak berlaku. 
Tap MPR No. III/MPR/2000 tentang Sumber Hukum dan Tata Urutan Peraturan UndangUndang.Berdasarkan ketetapan MPR tersebut, tata urutan peraturan perundang-undangan RI yaitu 1.UUD 1945;

2.Tap MPR;

3.UU;

4.Peraturan pemerintah pengganti UU;

5.PP;

6.Keppres;

7 Peraturan Daerah;Ketentuan dalam Tap MPR ini sudah tidak berlaku.

Undang-Undang Nomor 10 Tahun 2004 tentang Pembentukan Peraturan Perundangundangan.

Berdasarkan ketentuan ini, jenis dan hierarki Peraturan Perundang-undangan Republik Indonesia adalah sebagai berikut :

1.UUD Negara Republik Indonesia Tahun 1945;

2.UU/Perppu;

3.Peraturan Pemerintah;

4.Peraturan Presiden;

5.Peraturan Daerah.Ketentuan dalam Undang-Undang ini sudah tidak berlaku.

Undang-Undang Nomor 12 Tahun 2011 tentang Pembentukan Peraturan Perundangundangan.

Berdasarkan ketentuan dalam Undang-Undang ini, jenis dan hierarki peraturan perundangundangan Republik Indonesia adalah sebagai berikut : 
1.UUD Negara Republik Indonesia Tahun 1945;

2. Ketetapan MPR;

3. UU/Perppu;

4.Peraturan Presiden;

5.Peraturan Daerah Provinsi;

6.Peraturan Daerah Kabupaten/Kota.

\section{Tujuan Hukum Tata Negara}

Berikut adalah beberapa tujuan dari hukum tata negara

1.Menyebarluaskan pengertian-pengertian baru yang terkandung pada Undang-Undang Dasar Negara Republik Indonesia Tahun 1945 pasca-amandemen.

2.Mendorong supaya muncul kesadaran warga negara Indonesia akan hak dan kewajiban asasinya sebagai subjek Hukum Tata Negara Indonesia berdasarkan Undang-Undang Dasar Negara Republik Indonesia Tahun 1945.

3.Membantu para pemula memahami garis besar ruang lingkup ilmu pengetahuan tentang Hukum Tata Negara.

4.Mengakrabkan masyarakat Indonesia dengan pengetahuan tentang Hukum Tata Negara.

5.Mendorong perkembangan lebih lanjut Studi tentang Hukum Tata Negara di Indonesia. 


\section{Fungsi Hukum Tata Negara}

1.Hukum tata negara sebagai alat ketertiban dan keteraturan masyarakat

2.Hukum tata negara sebagai sarana untuk mewujudkan keadilan sosial lahir batin

3.Hukum tata negara sebagai sarana penggerak pembangunan

4.Fungsi kritis dari hukum tata negara adalah daya kerja hukum tidak semata-mata melakukan pengawasan pada aparatur penegak hukum termasuk yang ada di dalamnya

\section{Asas-asas Hukum Tata Negara}

\section{Asas Pancasila}

Asas pancasila adalah sumber hukum materil karena itu setiap pengaturan isi peraturan perundangan tidak boleh bertentangan pada Pancasila dan bila terjadi maka peraturan tersebut harus segera dicabut.

Pancasila sebagai asas Hukum Tata Negara bisa dilihat dari:

Asas Ketuhanan Yang Maha Esa (Sila Ke-1).

Asas Prikemanusiaan (Sila Ke-2).

Asas Kebangsaan (Sila Ke-3).

Asas Kedaulatan Rakyat (Sila Ke-4)

Asas keadilan (Sila Ke-5) 


\section{Asas Kedaulatan Rakyat}

Dalam Hukum Tata Negara pengertian kedaulatan bisa relatif, maksudnya bahwa kedaulatan itu tidak hanya dikenal pada negara-negara yang memiliki kekuasaan penuh keluar dan kedalam tapi juga dapat dikenakan kepada negara-negara yang berhubungan pada sebuah perjanjian yang berbentuk traktat atau dalam bentuk konfederasi atau federasi.kedaulatan tersebut tidak terpecah-pecah karena dalam suatu negara hanya ada satu kekuassan yang teringgi.

Kedaulatan rakyat adalah bahwa rakyatlah yang memiliki wewenang yang tertinggi yang menentukan segala wewenang dalam negara kedaulatan rakyat diwakilkan pada MPR, kekuasaan majelis itu nyata dan ditentukan oleh UUD tapi oleh karena majelis merupakan sebuah badan yang besar dan lamban sifatnya maka ia menyerahkan lagi kepada badan-badan yang ada dibawahnya.

\section{Asas Negara Hukum}

Yang dimaksud dengan Negara Hukum adalah Negara yang berdiri di atas hukum yang menjamin keadilan pada warga Negaranya. Keadilan adalah syarat bagi tercapainya kebahagiaan hidup untuk warga negaranya, dan sebagai dasar dari pada keadilan perlu di ajarkan rasa susila pada setiap manusia supaya dia menjadi warga Negara yang baik. Demikian pula peraturan hukum yang sebenarnya hanya ada bila peraturan hukum itu mencerminkan keadilan bagi pergaulan hidup antar warga negaranya. 


\section{Asas Pembagian Kekuasaan}

Pengertian pembagian kekuasaan beda dari pengertian pemisahan kekuasaan. Pemisahan kekuasaan artinya bahwa kekuasaan Negara itu terpisah-pisah dalam beberapa bagian, baik mengenai orangnya ataupun fungsinya. Kenyataan menunujukan bahwa sebuah pemisahan kekuasaan murni tidak bisa dilaksanakan. Karena itu pilihan jatuh kepada istilah pembagian kekuasaan yang artinya bahwa kekuasaan itu dibagi-bagi dalam beberapa bagian, namun tidak dipisahkan. Hal membawa konsekuensi bahwa di antara bagian-bagian tersebut dimungkinkan adanya kerjasama.

\section{Asas Negara Kesatuan}

Salah satu cara untuk menjaga keutuhan negara ini yakni dengan membentuk hukum tata negara yang bisa menjaga persatuan dan kesatuan bangsa ini. Terkandung dalam UUD 1945, pasal 1 ayat (1) sudah ditegaskan bahwa Indonesia merupakan suatu negara kesatuan yang berbentuk republik. Setiap hukum tata negara yang hendak dibentuk harus memperhatikan pada hal ini.

Tidak dibenarkan adanya materi di dalam hukum tata negara yang mempunyai peluang untuk memecah belah bangsa ini. Oleh sebab itu, salah satu tahapan kebijakan publik adalah menguji kebijakan publik, semata untuk mencegah supaya kebijakan publik tersebut berpotensi menjadi penyebab konflik sosial. 


\section{C.PENUTUP}

Hukum tata negara adalah peraturan-peraturan yang mengatur organisasai Negara dari tingkat atassampai bawah,sturktur,tugas\&wewenang alat perlengkapan negara hubungan antara perlengkapan tersebut secara hierarki maupun horizontal,wilayah negara,kedudukan warganegara serta hak-hak asasnya.

Selain kita mempelajari tentang pengertian hokum tata negara kita juga dapat mengetahui apa saja yang dipelajari dalam hokum tata negara yang dapat kita pelajari dari hokum tata negara adalah mempelajari berbagai teori dan pratik dalam penyelenggaraan hokum tata negara yang ada diberbagai negara.

Hukum tata negara juga memiliki beberapa tujuan yang mana salah satu dari tujuan hukum tata negara ini adalah untuk mendorong masyarakat untuk meningkatkan studi tentang hukum tata negara itu sendiri,yang mana maksud dari meningkatkan studi itu agar kita sebagai masyarakat paham akan apa itu hukum tata negara.

Didalam hokum tata Negara terdapat beberapa asas yang mana asas tersebut adalah asas pancasila,asas kedaulatan rakyat,asas Negara hukum,asas pembagian kekuasaan,dan yang terakhir adalah asas Negara kesatuan. 


\section{Daftar Pustaka}

Andrew Shandy Utama, Independensi Pengawasan Terhadap Bank Badan Usaha Milik Negara (Bumn) Dalam Sistem Hukum Nasional Di Indonesia, Soumatera Law Review, Volume 1, Nomor 1, 2018, 10.22216/soumlaw.v1i1.3312.

Annisa Arifka, Sanksi Administrasi Bagi Wajib Pajak Pajak Penghasilan Orang Pribadi Di Kota Padang, Soumatera Law Review, Volume 1, Nomor 2, 2018, 10.22216/soumlaw.v1i2.3745.

Ade Sarmini, Kualitas Pelayanan Surat Izin Mengemudi (SIM) Pada Kantor Satuan Lalu Lintas Polres Karimun, Soumatera Law Review, Volume 2, Nomor 2, 2019, 10.22216/soumlaw.v2i2.4231.

Bram Mohammad Yasser, Pengujian Unsur Penyalahgunaan Wewenang Pada Peradilan Tata Usaha Negara Dalam Kaitannya Dengan Tindak Pidana Korupsi, Soumatera Law Review, Volume 2, Nomor 1, 2019, 10.22216/soumlaw.v2i1.3558.

Danel Aditia Situngkir, Asas Legalitas Dalam Hukum Pidana Nasional Dan Hukum Pidana Internasional, Soumatera Law Review, Volume 1, Nomor 1, 2018, 10.22216/soumlaw.v1i1.3398.

Darmini Roza, Laurensius Arliman S, Peran Pemerintah Daerah Di Dalam Melindungi Hak Anak Di Indonesia, Masalah-Masalah Hukum, Volume 47, Nomor 1, 2018. https://doi.org/10.14710/mmh.47.1.2018.10-21.

Darmini Roza, Laurensius Arliman S, Peran Pemerintah Daerah untuk Mewujudkan Kota Layak Anak di Indonesia, Ius Quia Iustum Law Journal, Volume 25, Nomor 1, 2018, https://doi.org/10.20885/iustum.vol25.iss1.art10.

Darmini Roza, Laurensius Arliman S, Peran Badan Permusyawaratan Desa di Dalam Pembangunan Desa dan Pengawasan Keuangan Desa, Padjadjaran Journal of Law, Volume 4, Nomor 3, 2017. https://doi.org/10.15408/jch.v4i2.3433.

Debora Angelia Pardosi, Peran Jabatan Fungsional Auditor Terhadap Peningkatan Kinerja Birokrat Di Lingkungan Inspektorat Provinsi Jawa Tengah, Soumatera Law Review, Volume 1, Nomor 2, 2018, 10.22216/soumlaw.v1i2.3718.

Dewi Fiska Simbolon, Kurangnya Pendidikan Reproduksi Dini Menjadi Faktor Penyebab Terjadinya Pelecehan Seksual Antar Anak, Soumatera Law Review, Voume 1, Nomor 1, 2017, http://doi.org/10.22216/soumlaw.v1i1.3310.

Dian Bakti Setiawan, Keberadaan Dan Penerapan Peraturan Daerah Syariah Sebagai Perundang-Undangan Pada Tingkat Daerah, Soumatera Law Review, Volume 1, Nomor 1, 2018, 10.22216/soumlaw.v1i1.3327.

Dila Andika Azhar, Analisis Yuridis Terhadap Penyimpanan Sertifikat Hak Atas Tanah Oleh Notaris Pada Proses Pengikatan Jual Beli (Pjb) (Analisis Putusan Nomor 53/Pid.B/2017/Pn.Bkt), Soumatera Law Review, Volume 2, Nomor 1, 2019, 10.22216/soumlaw.v2i1.3557.

Dola Riza, Hakikat KTUN Menurut Undang-undang Peradilan Tata Usaha Negara Vs Undangundang Admnistrasi Pemerintahan, Soumatera Law Review, Volume 2, Nomor 2, 2019, 10.22216/soumlaw.v2i2.3566.

Fadlan, Perkembangan Kebijakan Daerah Sebagai Paradigma Dasar Untuk Penentuan Kebijakan Mengelola Potensi Keberagaman, Soumatera Law Review, Volume 2, Nomor 1, 2019, 10.22216/soumlaw.v2i1.3347. 
Ferdian, Lelang Terhadap Objek Jaminan Fidusia Yang Dirampas Oleh Negara Berdasarkan Putusan Pengadilan Negeri Di Kantor Pelayanan Kekayaan Negara Dan Lelang Padang, Soumatera Law Review, Volume 2, Nomor 1, 2019, 10.22216/soumlaw.v2i1.3564.

Hasnati, Tanggung Jawab Direksi Terhadap Terjadinya Kredit Macet Pada Perbankan Berdasarkan Undang-Undang Nomor 40 Tahun 2007, Soumatera Law Review, Volume 2, Nomor 1, 2019, 10.22216/soumlaw.v2i1.3319.

Hendra Sudrajat, Beggy Tamara, Peran Naskah Akademik Dan Daftar Inventarisasi Masalah Dalam Mewujudkan Peraturan Daerah Nomor 2 Tahun 2015 Tentang Perlindungan Anak Yang Aspiratif Di Kota Tangerang, Soumatera Law Review, Volume 1, Nomor 2, 2018, 10.22216/soumlaw.v1i2.3713.

Idham, Pendaftaran Tanah Dan Penerbitan Sertipikat Dalam Perspektif Free Trade Zone (FTZ) Di Kampung Tua, Kota Batam, Provinsi Kepulauan Riau, Soumatera Law Review, Volume 2, Nomor 1, 2019, 10.22216/soumlaw.v2i1.3908.

Jasmir, Pengembalian Status Hukum Tanah Ulayat Atas Hak Guna Usaha, Soumatera Law Review, Volume 1, Nomor 1, 2018, 10.22216/soumlaw.v1i1.3384.

Laurensius Arliman S, Lembaga-Lembaga Negara (Di Dalam Undang-Undang Dasar Negara Republik Indonesia Tahun 1945), Deepublish, Yogyakarta, 2016.

Laurensius Arliman S, Perlindungan Anak (Dari Undang-Undang Perlindungan Anak, UndangUndang Sistem Peradilan Pidana Anak, Wacana Kebiri Dan Bahaya LGBT Bagi Regenarasi Bangsa), Deepublish, Yogyakarta, 2016.

Laurensius Arliman S, Gokma Toni Parlindunga S, Politik Hukum Perlindungan Anak, Deepublish, Yogyakarta, 2017.

Laurensius Arliman S, Kedudukan KPAI dalam Struktur Ketatanegaraan Republik Indonesia, Deepublish, Yogyakarta, 2019.

Laurensius Arliman S, Pendidikan Kewarganegaraan - Tantangan Warga Negara Milineal Menghadapi Revolusi Industri 4.0, Yogyakarta, 2019.

Laurensius Arliman S, Protection of Girls from the Dangers of Sexual Violence in Indonesia to Design Suistanable Child Protection, Proceedings 1st Bicoshs (Prophetic Role of Sharia Knowledge in Developing Social Justice), 2017.

Laurensius Arliman S, Debora Angelina Carissa Pardosi, Peran Badan Pengawas Pemilu untuk Mengisi Kekosongan Hukum Eksploitasi Anak dalam Pelaksanaan Kampanye, Seminar Nasional Hukum Universitas Negeri Semarang, Volume 4, Nomor 2, 2018, https://doi.org/10.15294/snh.v4i02.25600.

Laurensius Arliman S, Danel Situngkir, Rianda Putri, Rahmat Fauzi, Hariyadi, Gokma Toni Parlindungan S, Cyber Bullying Against Children In Indonesia, International Conference on Social Sciences, Humanities, Economics and Law; Padang, 2018. DOI:10.4108/eai.5-92018.2281372.

Laurensius Arliman S, Penelantaran Perlindungan Anak Oleh Orangtua Akibat Gaya Hidup Modernisasi Yang Salah Arah, Konferensi Nasional Sosiologi V, Asosiasi Program Studi Sosiologi Indonesia, Volume 5, Padang 18-19 Mei 2017.

Laurensius Arliman S, Penegakan Hukum Bisnis Ditinjau Dari Undang-Undang Larangan Praktek Monopoli Dan Persaingan Usaha Tidak Sehat, Lex Jurnalica, Volume 16, Nomor 3, 2019.

Laurensius Arliman S, Analisis Dari Perspektif Politik Hukum Terhadap Pasal 56 UndangUndang Nomor 8 Tahun 1981 Tentang Kitab Undang Undang Hukum Acara Pidana, Lex Jurnalica, Volume 15, Nomor 3, 2018.

Laurensius Arliman S, Perlindungan Hukum Terhadap Karya Desain Industri Di Indonesia, Lex Jurnalica, Volume 15, Nomor 2, 2018. 
Laurensius Arliman S, Perlindungan Hak Anak Di Dalam Memperoleh Pelayanan Kesehatan Di Indonesia, Lex Jurnalica, Volume 15, Nomor 1, 2018.

Laurensius Arliman S, Perlindungan Hak Anak Yang Berhadap Dengan Hukum Di Wilayah Hukum Polisi Resort Kota Sawahlunto, Lex Jurnalica, Volume 14, Nomor 2, 2018.

Laurensius Arliman S, Kedudukan Lembaga Perlindungan Saksi Dan Korban Terhadap Perlindungan Hak Anak Yang Bekelanjutan Di Indonesia, Lex Jurnalica, Volume 14, Nomor 1, 2018.

Laurensius Arliman S, Perlindungan Hukum UMKM Dari Eksploitasi Ekonomi Dalam Rangka Peningkatan Kesejahteraan Masyarakat, Jurnal RechtsVinding, Volume 6, Nomor 3, 2017.

Laurensius Arliman S, Partisipasi Masyarakat Di Dalam Perlindungan Anak Yang Berkelanjutan Sebagai Bentuk Kesadaran Hukum, Padjadjaran Journal of Law, Volume 3, Nomor 2, 2016. https://doi.org/10.22304/pjih.v3n2.a5.

Laurensius Arliman S, Penanaman Modal Asing Di Sumatera Barat Berdasarkan UndangUndang Nomor 25 Tahun 2007 Tentang Penanaman Modal, Supremasi Hukum, Volume 1, Nomor 1, 2018. http://dx.doi.org/10.36441/hukum.v1i01.102.

Laurensius Arliman S, Kodifikasi RUU KUHP Melemahkan Komisi Pemberantasan Korupsi, UIR Law Review, Volume 2, Nomor 1, 2018 https://doi.org/10.25299/uirlrev.2018.2.01.1437.

Laurensius Arliman S, Perlindungan Hukum Terhadap Anak Yang Tereksploitasi Secara Ekonomi Di Kota Padang, Jurnal Arena Hukum, Volume 9, Nomor 1, 2016, https://doi.org/10.21776/ub.arenahukum.2016.00901.5

Laurensius Arliman S dan Hariyadi, Peran Orangtua Dalam Mengawasi Anak Dalam Mengakses Media Internet Untuk Mewujudkan Perlindungan Hak Anak, Soumatera Law Review, Volume 1, Nomor 2, 2018, http://doi.org/10.22216/soumlaw.v1i2.3716.

Laurensius Arliman S, Peran Investasi dalam Kebijakan Pembangunan Ekonomi Bidang Pariwisata di Provinsi Sumatera Barat, Kanun Jurnal Ilmu Hukum, Volume 20, Nomor 2, 2018, https://doi.org/10.24815/kanun.v20i2.10081.

Laurensius Arliman S, Perlindungan Hukum Bagi Anak Dalam Perspektif Pancasila Dan Bela Negara, Jurnal Ilmu Hukum Unifikasi, Volume 5, Nomor 1, 2018, https://doi.org/10.25134/unifikasi.v5i1.754.

Laurensius Arliman S, Hukum Adat Di Indonesia Dalam Pandangan Para Ahli Dan Konsep Pemberlakuannya di Indonesia, Jurnal Selat, Volume 5, Nomor 2, 2018, https://doi.org/10.31629/selat.v5i2.320.

Laurensius Arliman S, Perkembangan Dan Dinamika Hukum Ketenagakerjaan Di Indonesia, Jurnal Selat, Volume 5, Nomor 1, 2017.

Laurensius Arliman S, Peran Pemerintah Daerah Dalam Perlindungan Hak Anak Berdasarkan Undang-Undang Nomor 35 Tahun 2014 Tentang Perlindungan Anak, Jurnal Yustisia, Volume 22, Nomor 1, 2015.

Laurensius Arliman S, Eksistensi Hukum Lingkungan dalam Membangun Lingkungan Sehat Di Indonesia, Jurnal Lex Librum, Volume 5, Nomor 1, 2018, http://doi.org/10.5281/zenodo.1683714.

Laurensius Arliman S, Perlindungan Anak Oleh Masyarakat Ditinjau Dari Mazhab Sejarah Di Dalam Penerapan Prinsip The Best Interest Of The Child Pada Kehidupan Anak Di Indonesia, Era Hukum-Jurnal Ilmiah Ilmu Hukum, Volume 15, Nomor 1, 2017, http://dx.doi.org/10.24912/era\%20hukum.v15i1.668.

Laurensius Arliman S, Reformasi Penegakan Hukum Kekerasan Seksual Terhadap Anak Sebagai Bentuk Perlindungan Anak Berkelanjutan, Kanun Jurnal Ilmu Hukum, Volume 19, Nomor 2, 2017. 
Laurensius Arliman S, Tinjauan Kedudukan Pengguna Anggaran Dan Kuasa Pengguna Anggaran, $\quad$ Volume $\quad$, Nomor $\quad 2, ~ 2015$, https://doi.org/10.21776/ub.arenahukum.2015.00802.1

Laurensius Arliman S, Penyelesaian Konflik Antar Umat Beragama (Studi Pada Komnas HAM Perwakilan Sumatera Barat), Padjadjaran Jurnal Ilmu Hukum, 2015,

Laurensius Arliman S, Imelda Tamba, Maria Florida Bunga Makin, Kualitas Pelayanan Sdm Mempengaruhi Kepuasan Anggota Koperasi Simpan Pinjam Credit Union Jembatan Kasih Kp Tanjung Uncang Di Kota Batam, Jurnal Marketing, Volume 1, Nomor 1, 2018.

Laurensius Arliman S, Fungsi Badan Kehormatan Dewan Perwakilan Rakyat Daerah Kota Padang, Jurnal Ilmiah Hukum De'Jure, Volume 1, Nomor 2, 2017.

Laurensius Arliman S, Urgensi Notaris Syari'ah Dalam Bisnis Syari'ah Di Indonesia, Walisongo: Jurnal Penelitian Sosial Keagamaan, Volume 24, Nomor 1, Mei 2016, DOI: http://dx.doi.org/10.21580/ws.2016.24.1.676.

Laurensius Arliman S, Pendidikan Paralegal Kepada Masyarakat Sebagai Bentuk Perlindungan Anak Yang Berkelanjutan, UIR Law Review, Volume 1, Nomor 1, 2017, https://doi.org/10.25299/ulr.2017.1.01.153

Laurensius Arliman S, Peran Lembaga Catatan Sipil Terhadap Perkawinan Campuran Berdasarkan Undang-Undang Perkawinan, Cendekia Hukum, Volume 4, Nomor 2, 2019, http://doi.org/10.33760/jch.v4i2.40.

Laurensius Arliman S, Partisipasi Masyarakat di Daerah Perbatasan NKRI untuk Mencegah Anak Sebagai Objek Human Trafficking, Wawasan Yuridika, Volume 2, Nomor 1, 2018, http://dx.doi.org/10.25072/jwy.v2i1.162.

Laurensius Arliman S, Memperkuat Kearifan Lokal Untuk Menangkal Intoleransi Umat Beragama Di Indonesia, Ensiklopedia of Journal, Volume 1, Nomor 1, 2018, https://doi.org/10.33559/eoj.v1i1.18.

Laurensius Arliman S, Perkawinan Antar Negara Di Indonesia Berdasarkan Hukum Perdata Internasional, Kertha Patrika, Volume 39, Nomor 3, 2017, https://doi.org/10.24843/KP.2017.v39.i03.p03.

Laurensius Arliman S, Komisi Penyiaran Indonesia Sebagai State Auxialiary Bodies Yang Menjamin Siaran Yang Layak Bagi Anak, Veritas et Justitia, Volume 3, Nomor 1, 2017, https://doi.org/10.25123/vej.2528.

Laurensius Arliman S, Partispasi Pemerintah Daerah Di Dalam Perlindungan Anak Yang Berkelanjutan Di Indonesia, Jurnal Ilmu Hukum, Volume 7, Nomor 2, 2016.

Laurensius Arliman S, Sumbangsih Werda Notaris Dalam Organisasi Ikatan Notaris Indonesia, Jurnal Yuridika, Volume 30, Nomor 3, 2015, https://doi.org/10.20473/ydk.v30i3.1770.

Laurensius Arliman S, Peran Dewan Pers Sebagai Lembaga Negara Independen Yang Menjamin Berita Yang Layak Bagi Perlindungan Anak, Mahkamah: Jurnal Kajian Hukum Islam, Volume 4, Nomor 2, 2019, https://doi.org/10.24235/mahkamah.v4i2.4972.

Laurensius Arliman S, Menjerat Pelaku Penyuruh Pengrusakan Barang Milik Orang Lain Dengan Mempertimbangkan Asas Fungsi Sosial Kajian Putusan Nomor 267/Pid. B/2015/PN. Blg, Jurnal Gagasan Hukum, Volume 01, Nomor 1, 2019,

Laurensius Arliman S, Partisipasi Masyarakat Di Dalam Pengelolaan Uang Desa Pasca Undang-Undang Nomor 6 Tahun 2014 Tentang Desa, Jurnal Arena Hukum, Volume 12, Nomor 2, 2019, https://doi.org/10.21776/ub.arenahukum.2019.01202.5.

Laurensius Arliman S, Pelaksanaan Penyidikian Tindak Pidana Penghinaan Terhadap Agama Melalui Konten Video Melalui Media Sosial, Ensiklopedia Sosial Review, Volume 01, Nomor 1, 2019. 
Laurensius Arliman S, Perlindungan Anak dalam Proses Penyidikan di Polresta Padang, Jurnal Ijtihad, Volume 31, Nomor 2, 2015, http://dx.doi.org/10.15548/ijt.v31i2.63,

Laurensius Arliman S, Yulfasni, Tanggung Jawab Perseroan Terbatas Dihubungkan dengan Good Corporate Governance dalam Rangka Mencegah Penyalahgunaan Kekuasaan Pemegang Saham, Pagaruyuang Law Journal, Volume 3, Nomor 1, 2019.

Laurensius Arliman S, Surat Dakwaan dalam Hukum Acara Pidana Sebagai Bentuk Mendukung Penegakan Hukum di Indonesia, Kosmik Hukum, Volume 19, Nomor 1, 2019, https://doi.org//10.30595/kosmikhukum.v19i1.4081.

Laurensius Arliman S, Mewujudkan Penegakan Hukum Yang Baik Di Negara Hukum Indonesia, Dialogica Jurnalica, Volume 11, Nomor 1, 2019, https://doi.org/10.28932/di.v11i1.1831.

Laurensius Arliman S, Politik Hukum Kenotariatan Pasca Perubahan Undang-Undang Jabatan Notaris Bagi Notaris Dalam Menjalankan Jabatannya, Dialogica Jurnalica, Volume 9, Nomor 2, 2018, https://doi.org/10.28932/di.v9i2.976.

Laurensius Arliman S, Mediasi Melalui Pendekatan Mufakat Sebagai Lembaga Alternatif Penyelesaian Sengketa Untuk Mendukung Pembangunan Ekonomi Nasional, UIR Law Review, Volume 2, Nomor 2, 2018, https://doi.org/10.25299/uirlrev.2018.vol2(02).1587.

Laurensius Arliman S, Jaksa Sebagai Pengacara Negara Menurut Undang-undang Kejaksaaan, Jendela Hukum dan Keadilan, Volume 5, Nomor 1, 2018.

Laurensius Arliman S, Pemakzulan Presiden Dan Wakil Presiden Di Indonesia, Justicia et Pax, Volume 34, Nomor 1, 2018, https://doi.org/10.24002/jep.v34i1.1652.

Laurensius Arliman S, Implementasi Keterbukaan Informasi Pubik Untuk Mendukung Kinerja Aparatur Sipil Negara Yang Profesional, Cendikia Hukum, Volume 3, Nomor 2, 2018, http://doi.org/10.33760/jch.v3i2.18.

Laurensius Arliman S, Peranan Pers Untuk Mewujudkan Perlindungan Anak Berkelanjutan Di Indonesia, Jurnal Ilmu Hukum Tambun Bungai, Volume 2, Nomor 2, 2017.

Laurensius Arliman S, Kedudukan Komisi Perlindungan Anak Indonesia Sebagai State Auxiliary Bodies Dalam Sistem Hukum Ketatanegaraan Indonesia, Justitia et Pax, Volume 32, Nomor 2, 2016, https://doi.org/10.24002/jep.v32i2.1151.

Laurensius Arliman S, Pelaksanaan Penanganan Tindak Pidana Narkotika Oleh Sudbit Keamanan Dengan Subdit Narkotika Kepolisian Daerah Sumatera Barat, Journal of Islamic and Law Studies, Volume 3, Nomor 2, 2019, https://doi.org/10.18592/jils.v3i2.3237.

Laurensius Arliman S, Konsep dan Gagasan Pengenalan Pendidikan Antikorupsi Bagi Anak dalam Rangka Mewujudkan Generasi yang Bebas Korupsi, Nurani: Jurnal Kajian Syari'ah dan Masyarakat, Volume 17, Nomor 1, 2017, https://doi.org/10.19109/nurani.v17i1.1348.

Laurensius Arliman S, Dinamika Dan Gagasan Mencegah Eksploitasi Anak Dalam Pemilihan Umum Kepala Daerah, Jurnal Jentera, Volume 1, Nomor 1, 2017.

Laurensius Arliman S, Perlindungan Terhadap Anak Sebagai Salah Satu Wujud Tujuan Bela Negara, Respublica, Volume 17, Nomor https://doi.org/10.31849/respublica.v17i1.1453.

Laurensius Arliman S, Komnas Perempuan Sebagai State Auxialiary Bodies Dalam Penegakan Ham Perempuan Indonesia, Justicia Islamica, Volume 14, Nomor 2, 2017, https://doi.org/10.21154/justicia.v14i2.1228.

Laurensius Arliman S, Hukum Pidana Sebagai Landasan Penegakan Hukum Oleh Penegak Hukum Di Indonesia, Jurnal Jendela Hukum dan Keadilan, Volume 4, Nomor 2, 2017.

Laurensius Arliman S, Politik Hukum Pembentukan Undang-Undang Perlindungan Anak Untuk Mewujudkan Perlindungan Anak Yang Berkelanjutan, Syiar Hukum, Volume 15, Nomor 2, 2017, https://doi.org/10.29313/sh.v15i2.2857. 
Laurensius Arliman S, Undang-undang 17 Tahun 2016 Tentang Penetapan Perppu 1 Tahun 2016 Sebagai Wujud Perlindungan Anak Ditinjau Dari Perspektif Hukum Tata Negara, Jurnal Hukum Positum, Volume 1, Nomor 2, 2017, http://dx.doi.org/10.35706/positum.v1i2.846.

Laurensius Arliman S, Hak Atas Pengadaan Dan Standar Rumah Bagi Mantan Presiden Dan/Atau Wakil Presiden Republik Indonesia, Jurnal Yuridis, Volume 4, Nomor 1, 2017, http://dx.doi.org/10.35586/.v4i1.131.

Laurensius Arliman S, Pengadilan Hak Asasi Manusia Dari Sudut Pandang Penyelesaian Kasus Dan Kelemahannya, Jurnal Ilmu Hukum Tambun Bungai, Volume 2, Nomor 1, 2017.

Laurensius Arliman S, Pemanggilan Notaris Dalam Rangka Penegakan Hukum Paska Perubahan Undang-Undang Jabatan Notaris, Justicia et Pax, Volume 32, Nomor 1, 2016, https://doi.org/10.24002/jep.v32i1.758.

Laurensius Arliman S, Perlindungan Hukum Terhadap Anak Yang Tereksploitasi Secara Ekonomi Di Kota Padang, Arena Hukum, Volume 9, Nomor 1, 2016, https://doi.org/10.25123/vej.2076.

Laurensius Arliman S, Tinjauan Kedudukan Pengguna Anggaran dan Kuasa Pengguna $\begin{array}{lllll}\text { Anggaran, } & \text { Volume } & 8, & \text { Nomor } & 2,\end{array}$ https://doi.org/10.21776/ub.arenahukum.2015.00802.1.

Laurensius Arliman S, Bolehkan Notaris Melakukan Penyuluhan Hukum Pasar Modal Melalui Media Internet? Jurnal Hukum dan Bisnis (Selisik), Volume 2, Nomor 1, 2016, https://doi.org/10.35814/selisik.v2i1.638.

Laurensius Arliman S, Hak Ingkar (Verschoningsplicht) Atau Kewajiban Ingkar (Verschoning Splicht) Notaris Didalam Undang-Undang Jabatan Notaris, Doctrinal, Volume 1, Nomor $1,2016$.

Laurensius Arliman S, Peranan Filsafat Hukum Dalam Perlindungan Hak Anak Yang Berkelanjutan Sebagai Bagian Dari Hak Asasi Manusia, Doctrinal, Volume 1, Nomor 2, 2016.

Laurensius Arliman S, Partisipasi Aktif dan Pasif Publik dalam Pembentukan Peraturan Daerah di Kota Payakumbuh, Lex Librum: Jurnal Ilmu Hukum, Volume 2, Nomor 1, 2015.

Laurensius Arliman S, Wakil Menteri dalam Sistem Pemerintahan Indonesia, Jurnal Manajemen Sumber Daya Manusia, Volume 2, Nomor 2, 2015.

Laurensius Arliman S, Dispensasi Perkawinan Bagi Anak Di Bawah Umur Di Pengadilan Agama Padang Sidempuan, Jurnal Al Adalah, Volume 12, Nomor 4, 2015.

Laurensius Arliman S, Implikasi Putusan Mahkamah Konstitusi Dan Perubahan Undang Undang Jabatan Notaris Terhadap Pengawasan Notaris, Jurnal Respublica, Volume 16, Nomor 1, 2016, https://doi.org/10.31849/respublica.v16i1.1427.

Laurensius Arliman S, Wacana Program Pembangunan Nasional Semesta Berencana atau GBHN sebagai Landasan Pembangunan Negara Berkelanjutan, Jurnal Manajemen Pembangunan, Volume 3, Nomor 3, 2016.

Laurensius Arliman S, Gagalnya Perlindungan Anak Sebagai Salah Satu Bagian Dari Hak Asasi Manusia Oleh Orang Tua Ditinjau Dari Mazhab Utilitarianisme, Jurnal Yuridis, Volume 3, Nomor 2, 2016, http://dx.doi.org/10.35586/.v3i2.180.

Laurensius Arliman S, Mewujudukan Harmonisasi Lembaga Negara Independen Terhadap Konsep Perlindungan Hak Anak Yang Berkelanjutan, Jendela Hukum dan Keadilan, Volume 3, Nomor 2, 2016.

Laurensius Arliman S, Prostitusi Anak Laki-Laki Sebagai Kegagalan Perlindungan Anak, Istinbath, Volume 3, Nomor 2, 2016.

Laurensius Arliman S, Penyelenggaraan Sistem Presidensil Berdasarkan Konstitusi Yang Pernah Berlaku Di Indonesia, Jurnal Muhakamah, Volume 4, Nomor 2, 2019. 
Melki, Hubungan DPRD dan Pemerintah Daerah Dalam Penetapan Anggaran Pendapatan Dan Belanja Daerah, Soumatera Law Review, Volume 1, Nomor 1, 2018, 10.22216/soumlaw.v1i1.3385.

Muhammad Afif, Penemuan Hukum Oleh Hakim Terhadap Kasus Carok Akibat Sengketa Tanah Dalam Masyarakat Madura, Soumatera Law Review, Volume 1, Nomor 2, 2018, 10.22216/soumlaw.v1i2.3714.

Miszuarty Putri, Pelaksanaan Restitusi Bagi Anak Yang Menjadi Korban Tindak Pidana Sebagai Bentuk Pembaruan Hukum Pidana Berdasarkan Peraturan Pemerintah Nomor 43 Tahun 2017, Soumatera Law Review, Volume 2, Nomor 1, 2019, 10.22216/soumlaw.v2i1.3567.

Muhamad Rasyad, Pembuatan Akta Perdamaian Dalam Penyelesaian Sengketa Tanah Ulayat Melalui Notaris Di Kabupaten Agam, Soumatera Law Review, Volume 2, Nomor 1, 2019, 10.22216/soumlaw.v2i1.3569.

Muhammad Taufiqurrahman, Peran Perancang Peraturan Perundang-Undangan Kementerian Hukum dan Hak Asasi Manusia dalam Pengawasan Produk Hukum Daerah Melalui Executive Preview, Soumatera Law Review, Volume 2, Nomor 2, 2019, 10.22216/soumlaw.v2i2.4341.

Mardalena Hanifah, Perkawinan Beda Agama Ditinjau dari Undang-undang Nomor 1 Tahun 1974 Tentang Perkawinan, Soumatera Law Review, Volume 2, Nomor 2, 10.22216/soumlaw.v2i2.4420.

Oky Nasrul, Pemanfaatan Tanah Aset PT Kereta Api Indonesia (Persero) Divisi Regional II Sumatera Barat Oleh Pihak Ketiga, Soumatera Law Review, Volume 2, Nomor 1, 2019, 10.22216/soumlaw.v2i1.3554.

Rahmat Fauzi, Perkawinan Campuran Dan Dampak Terhadap Kewarganegaraan Dan Status Anak Menurut Undang-Undang Di Indonesia, Soumatera Law Review, Volume 1, Nomor 1, 2018, 10.22216/soumlaw.vli1.3395.

Rahmat Fauzi, Faisal, Efektifitas Mediasi Dalam Menyelesaikan Sengketa Perceraian (Study Di Pengadilan Agama Bukittinggi Dan Pengadilan Agama Payakumbuh Tahun 2015-2017), Soumatera Law Review, Volume 1, Nomor 2, 2018, 10.22216/soumlaw.v1i2.3722.

Rahmat Riardo, Konversi Hak Atas Tanah Ulayat Kaum Menjadi Hak Milik Melalui Program Pendaftaran Tanah Sistimatis Lengkap di Kota Solok, Soumatera Law Review, Volume 2, Nomor 2, 2019, 10.22216/soumlaw.v2i2.3566.

Rianda Prima Putri, Pemeriksaan Penggabungan Gugatan Ganti Kerugian Dalam Perkara Pidana Di Pengadilan Negeri Kelas 1B Bukittinggi, Soumatera Law Review, Volume 1, Nomor 1, 2018, 10.22216/soumlaw.v1i1.3348.

Ridwan Putra, Prospek Pembentukan Daerah Istimewa Sumatera Barat Dalam Koridor Negara Kesatuan Republik Indonesia, Soumatera Law Review, Volume 1, Nomor 2, 2018, 10.22216/soumlaw.v1i2.3529.

Rustan Sinaga, Peran Pengadilan Hubungan Industrial Pada Pengadilan Negeri Padang Kelas IA Dalam Memberikan Kepastian Hukum Terhadap Perkara Pemutusan Hubungan Kerja, Soumatera Law Review, Volume 1, Nomor 2, 2018, 10.22216/soumlaw.v1i2.3528.

Ratih Agustin Wulandari, Tata Kelola Perusahaan Oleh Direksi PT BPR Dharma Nagari Menerapakan Prinsip Good Corporate Governance, Soumatera Law Review, Volume 2, Nomor 2, 2019, 10.22216/soumlaw.v2i2.3568.

Rusmilawati Windari, Penanggulangan Eksploitasi Seksual Komersial Anak (ESKA) Berdasarkan Global - Local Based Approach (Glocalization), Soumatera Law Review, Volume 2, Nomor 2, 2019, 10.22216/soumlaw.v2i2.4369.

Sayid Anshar, Konsep Negara Hukum dalam Perspektif Hukum Islam, Soumatera Law Review, Volume 2, Nomor 2, 2019, 10.22216/soumlaw.v2i2.4136. 
Sandra Dewi, Mengenal Doktrin Dan Prinsip Piercing The Corporate Veil Dalam Hukum Perusahaan, Soumatera Law Review, Volume 1, Nomor 2, 2018, 10.22216/soumlaw.v1i2.3744.

Tommy Busnarma, Penerapan Sanksi Pidana Denda Terhadap Pelaku Tindak Pidana Penyalahgunaan Dan Peredaran Gelap Narkotika Di Pengadilan Negeri Padang, Soumatera Law Review, Volume 2, Nomor 1, 2019, 10.22216/soumlaw.v2i1.3559.

Wahyudi, Tanggungjawab Hukum Apoteker dalam Pemusnahan Obat Narkotika di Rumah Sakit, Soumatera Law Review, Volume 2, Nomor 2, 10.22216/soumlaw.v2i2.4484.

Yasmirah Mandasari, Sanksi Pidana Terhadap Kandungan Non Halal Terhadap Produk Makanan Bersertifikat Halal Yang Dilakukan Korporasi, Soumatera Law Review, Volume 2, Nomor 2, 2019, 10.22216/soumlaw.v2i2.4339.

Yohanis, Perkawinan Poligami Di Wilayah Hukum Pengadilan Agama Kota Padang (Mekanisime Pemberian Izin, Dasar Hukum, Syarat-Syarat Poligami Dan Pelaksanaanya), Soumatera Law Review, Volume 1, Nomor 1, 2018, 10.22216/soumlaw.v1i1.3403. 
